\title{
QUALITY ASSESSMENT OF SANDCRETE BLOCKS PRODUCED IN ADETA, KWARA STATE, NIGERIA
}

\author{
S. 0. Odeyemi ${ }^{1{ }^{*}}$, M. A. Akinpelu², O. D. Atoyebi ${ }^{3}$ and K. J. Orire ${ }^{4}$ \\ 1, 2, 4 Department of Civil EngineEring, KWARA State University, MALETE, KWARA STATE, NIGERIA \\ 3 DEPARTMENT OF CiVIL ENGINEERING, LANDMARK UNIVERSITY, OMU-ARAN, KWARA STATE, NIGERIA. \\ E-mail addresses.1 samson.odeyemi@kwasu.edu.ng. ${ }^{2}$ mutiu.akinpelu@kwasu.edu.ng, \\ 3atoyebi.olumoyewa@Imu.edu.ng, ${ }^{4}$ khadijatorire@gmail.com
}

\begin{abstract}
The durability of a building is determined to a great extent by the quality of materials used in its construction. Sandcrete block is a major building material in Nigeria. This research assessed the quality of blocks produced in Adeta, Ilorin West Local Government Area of Kwara State, Nigeria. Eight block factories were selected from the study area and the quality of their blocks were measured for their water absorption ratios and compressive strengths and compared with the Nigerian Industrial Standards (NIS) specifications. Six samples each of size 450mm x 225mm $x$ $225 \mathrm{~mm}$ per factory were tested. Experimental findings revealed that the absorption rate of the sandcrete blocks were higher than the $12 \%$ specification. The compressive strengths of the blocks which ranges from $0.19 \mathrm{~N} / \mathrm{mm}^{2}$ to $0.40 \mathrm{~N} / \mathrm{mm}^{2}$ fall below the minimum specification of $2.5 \mathrm{~N} / \mathrm{mm}^{2}$. Inadequate mix ratio is a factor that resulted in the poor quality sandcrete blocks produced in the area.
\end{abstract}

Keywords: Adeta, Compressive strength, Kwara State, Sandcrete blocks, Water Absorption

\section{INTRODUCTION:}

Building failures have resulted in loss of lives and properties in Nigeria [1]. In some cases, even though the building has not totally collapsed, the aesthetics value is lost to cracks and other defects. The concern for sudden building failure in Nigeria requests that materials used for construction of buildings meet minimum requirements. Housing is a necessity of man and the ambition of people to have access to decent shelter is not a luxury but a necessity. Different materials are used around the world for buildings [2]. Sandcrete block is a composite material made up of cement, sand and water which are moulded into diverse sizes. Freestanding walls and building structures with load bearing and non-load bearing sandcrete blocks are common in Nigeria because of their ease of construction and their affordability. Sandcrete skin panels and blocks are sometimes used to provide aesthetics to buildings and serve as control to moisture infiltration and wind action. This utility value of Sandcrete in comparison to its cost and its adaptability to climatic factors is responsible for its wide application; most especially in small to medium buildings in countries within tropical rainforests where a considerable amount of precipitation and high average temperatures are predominant [3].

Sandcrete blocks can either be solid or hollow rectangular types with $450 \mathrm{~mm} \times 225 \mathrm{~mm} \times 225 \mathrm{~mm}$ and $450 \mathrm{~mm} \times 150 \mathrm{~mm} \times 225 \mathrm{~mm}$ being the most common sizes [4]. Anosike and Oyebade [5] reported that the NIS specified two types of blocks, types A blocks which are load bearing and Type B blocks which are non-load bearing. Both of them can either be solid or hollow. Building factories in Nigeria habitually produce twocell hollow sandcrete blocks [16] There is a void from top to the bottom of hollow sandcrete blocks which occupy about one third of the volume of the blocks but solid sandcrete block does not have any void in it. Sandcrete blocks are relatively cheap when compared to other construction materials. They provide an excellent resistance to damage without the added cost of protection devices. Sandcrete blocks do not rust, decay, or provide a home for damaging insects as other building materials can. They do not contain any material that is harmful to the environment [6]. The minimum compressive strength of sandcrete stated in the Nigeria Industrial Standard [7] ranges between $2.5 \mathrm{~N} / \mathrm{mm}^{2}$ to $3.45 \mathrm{~N} / \mathrm{mm}^{2}$ for non-load bearing and load 
bearing walls respectively. This strength of sandcrete blocks can be greatly influenced by the production method, duration of curing, sizes of blocks and the properties of constituent materials.

This research work focused on the assessment of the quality of sandcrete blocks produced in Adeta, Ilorin West Local Government Area, Kwara State, Nigeria. Sandcrete block specimens from eight block factories in the study were tested and quality of the samples were evaluated as a measure of their water absorption rate and compressive strength values and compared with the provision of the Nigeria Industrial Standard.

\section{MATERIALS AND METHOD:}

The following materials were used in the production of sandcrete blocks:

\subsection{Cement}

Cement is a construction material used in bonding with stones, bricks and sand [8]. The principal constituents of cement are compounds of lime. When water is added to cement, hydration occurs and a large amount of heat is released. On hydration, gel is formed which binds the aggregate particles together and provides strength and water tightness to concrete on hardening. The most common type of cement for construction work is Ordinary Portland Cement (OPC) [5]. Portland cement to be used for the production of sandcrete blocks must comply with all the prescribed requirements in British Standard (BS-12) [9] and NIS 444-1:2003 [10] respectively.

\subsection{Aggregates}

The British Standard (BS-882) [11] defined aggregate as a granular material obtained by processing natural materials while Taylor [12] defined aggregates as mineral filler materials used in concrete. Aggregates are either natural or manufactured and occupy about $75 \%$ of the volume of concrete. Sand, gravel, crushed rock and other mineral fillers are used as aggregates. Aggregates are major components in the production of concrete [17].

\subsection{Water}

Water reacts with cement to bring about hydration. The workability and strength of sandcrete depends to a large extent on the amount of water used in mixing. Water to be used for the production of concrete or sandcrete must be free of suspended particles, inorganic salts, acids and alkalis, oil contamination and algae [13]. Potable water that meets the NIS 554:2007 [14]standard is recommended for the production of sandcrete blocks.

\subsection{Methods}

Eight (8) block factories were visited and six (6) samples each with dimensions $450 \mathrm{~mm} \times 225 \mathrm{~mm} \times$ $225 \mathrm{~mm}$ were purchased. The samples purchased were tested for their absorption and compressive strength being the two major characteristic requirements that the [7] specified for testing and verifying the quality of sandcrete block apart from the appearance and dimension. The batching methods and mix ratios, method of mixing and curing were observed at the various block manufacturing industries. Structured interview was conducted at each factory from some of the factory staff to elicit further information on their operations in order to give credibility to some of the observations made during the site visits. Samples of the fine aggregates used by the block factories were also tested for their specific gravity and particle size distribution in the laboratory. All tests were carried out at the laboratory of the Department of Civil Engineering, University of Ilorin, Ilorin, Nigeria.

\subsubsection{Sieve Analysis for Fine Aggregate}

Sieve analysis is a laboratory test that measures the particle size distribution of a soil by passing it through a series of sieves. Soil retained on it is termed as gravel fraction. A set of British standard (BS) sieves of sizes $1.0 \mathrm{~mm}, 0.85 \mathrm{~mm}, 0.60 \mathrm{~mm}, 0.50 \mathrm{~mm}, 0.30,0.25,0.180$ and pan and a weighing balance were used for the analysis. The sieves were arranged by keeping the largest aperture sieve at the top and smallest aperture at the bottom. A lid was placed at the top sieve and a pan at the bottom sieve.

The test was carried out for each aggregate sample collected from each of the block manufacturing industries using the following procedure:

The samples were spread out in the sun to dry for a period of 24 hours before the test was carried out. Five hundred grams $(500 \mathrm{~g})$ of each of the samples was weighed on a weighing balance and poured on the uppermost sieve. Sieve sizes for grading purposes which conforms to BS 882 (16) were utilized. The sieves were shaken mechanically. The residues retained on each sieve was weighed and recorded. The cumulative weight passing through each sieve was calculated as a percentage of the total sample weight.

\subsubsection{Soil grading: Uniformity Coefficient $c_{u}$}

The grading of soil is best determined by direct observation of its particle size distribution curve. Equation (1) was adopted in calculating the Uniformity coefficient.

$$
C_{u}=\frac{D_{60}}{D_{10}}
$$

Where $c_{u}$ is the Uniformity coefficient, $D_{60}$ is the particle diameter corresponding to $60 \%$ finer on the

Vol. 37, No. 1, January 2018 
cumulative particle-size distribution curve and $D_{10}$ is the particle diameter corresponding to $10 \%$ finer on the cumulative particle-size distribution curve. If $c_{u}<$ 4.0 the soil is poorly graded; if $c_{u}>4.0$ the soil is well graded.

\subsubsection{Specific Gravity}

Specific gravity is considered to be a measure of strength or quality of a material. The following apparatus were used to conduct the specific gravity test on the fine aggregates used in this research: Specific gravity bottle, distilled water and soil samples and the following procedure was adopted:

An Empty bottle was cleaned, weighed and designated (W1). The bottle was filled with one-third of the total volume of the sand sample, weighed and designated (W2). The bottle was filled with distilled water, weighed and designated (W3). Then the content of the bottle was discarded and it was rinsed thoroughly. The bottle was then filled with distilled water to the meniscus, weighed and designated (W4). The Specific gravity (SG) was calculated using equation (2)

$$
S G=\frac{W 2-W 1}{(W 4-W 1)-(W 3-W 2)}
$$

\subsubsection{Water Absorption rate}

Water absorption rate is determined by measuring the decrease in mass of saturated block and surface dry sample. A weighing balance and a curing tank were used in the water absorption test on the sandcrete block used for this research. The following steps were followed:

Samples from each block factory, whose weights had been taken in the dry state and noted as $\left(\mathrm{M}_{1}\right)$, was fully immersed in water. The time taken for full immersion was noted, and period of twenty-four (24) hours was allowed to elapse. After 24 hours, the weight of the wet block samples was recorded as $\left(\mathrm{M}_{2}\right)$. The difference between the dry and wet weights of each block was calculated by subtracting the dry weight from the wet weight. The percentage absorption was calculated using Equation (3).

Water absorption $(\%)=\frac{M 2-M 1}{M 1} \times 100$

\subsubsection{Compressive Strength}

Compressive strength is the ratio of the crushing load that a sample can sustain to its net area. A manual compression testing machine with a maximum load capacity of $1560 \mathrm{kN}$ was utilized for this test. A total of Forty-eight (48) samples produced from the different block factories were crushed in order to obtain their compressive strengths. The following procedure was followed:
The sandcrete blocks were tested on the 28th day of their production. The bearing surface of the compression testing Machine was wiped clean. Loose sand and other materials were removed from the ends of the specimen. Smooth surface wood (serving as base plate) was placed at the bottom and top of each specimen block so as to ensure uniform distribution of load for accurate crushing. The specimen was then placed in the machine and its axis carefully aligned with the centre of thrust of the spherically seated plate with a $20 \mathrm{~mm}$ thick base plate on the block to be tested in order to spread the load on the Sandcrete block. The machine was then put on and the applied load was gradually increased with a close observation on load and corresponding compression. As the load was being increased, it got to a point where the increment of load led to a disproportionate compression. The load was further increased and there was a corresponding increase in the compression till a point where the specimen fractures and break. The broken specimen was then removed from the machine with the aid of head pan, the machine was stopped and reading of the crushing load of the block was taken.

\section{RESULTS AND DISCUSSION}

The particle size distribution of the aggregates obtained from the eight (8) Block Manufacturing factories are shown in Figures 1 to 8.

It was observed from Figures 1 to 8 that the Uniformity Coefficient $\left(C_{u}\right)$ was $4.2 .9,5,4,7.5,2.53,4$ and 2.53 for Danzaria, Ilal-Amam, God is Able, M. Nuhu, Alasela, Alhaji Niyi, More and Wopa Block making factories respectively. The Uniformity coefficient results revealed that the fine aggregate used at Ilal Amam, Alhaji Niyi and Wopa block making factories were poorly graded while the others were well graded and met the requirement set by [7] for suitable sand to be used in the manufacture of sandcrete blocks.

Table 1 shows the result of the specific gravity tests for each soil samples collected from the eight (8) Block Industries investigated in this research. The results obtained for the eight (8) Block factories fall below the range of 2.6 to 2.7 specified for natural aggregates by Neville [15].

The mix ratios adopted by the eight (8) block factories in the production of their blocks is shown in Table 2. The Cement-Fine Aggregates mix ratios range from 1:10 to 1:14 which was used to produce a minimum of 35 to 45 blocks from a bag of Ordinary Portland cement. This mix ratio is far below the requirement set by the Nigerian Industrial Standard [7] which specified mix ratio 1:6 for load bearing blocks. 


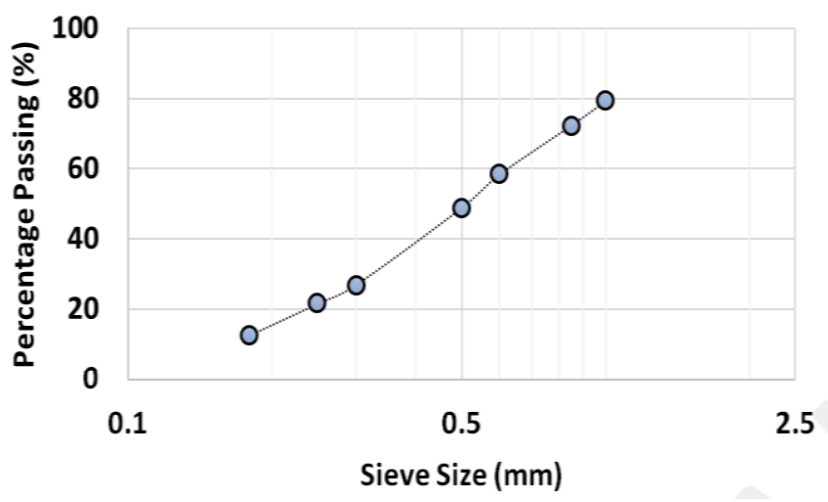

Figure 1: Particle Size Distribution Curve for Danzaria Block Factory

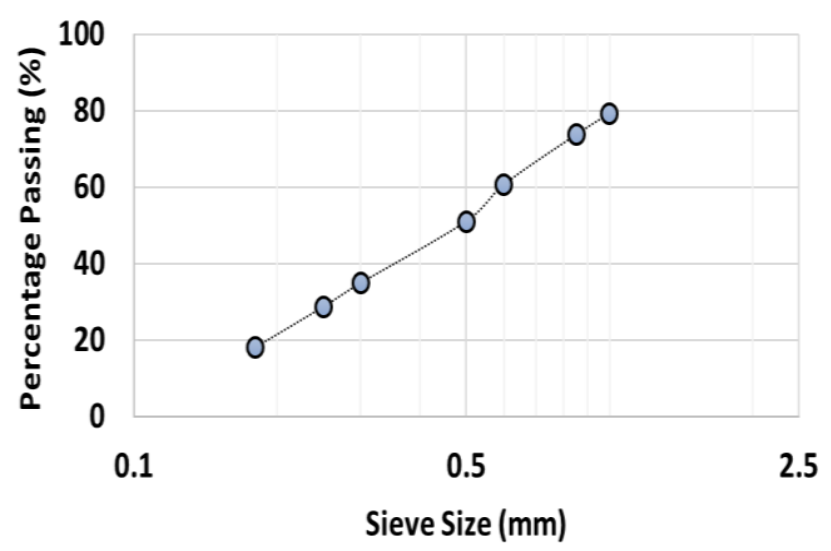

Figure 3: Particle Size Distribution Curve for God is Able Block Factory

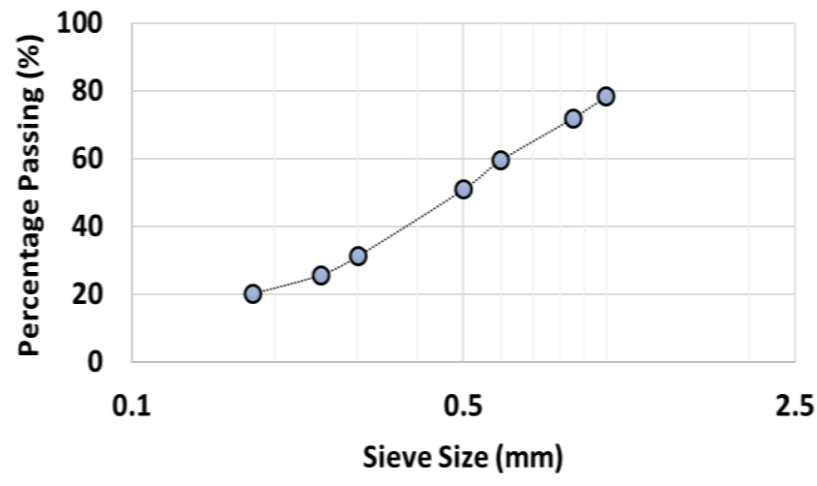

Figure 5: Particle Size Distribution Curve for Alasela Block Factory

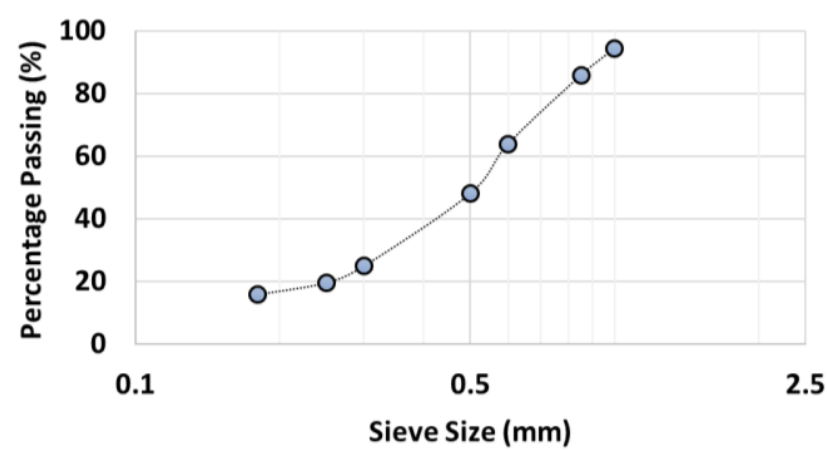

Figure 7: Particle Size Distribution Curve for More Block Factory

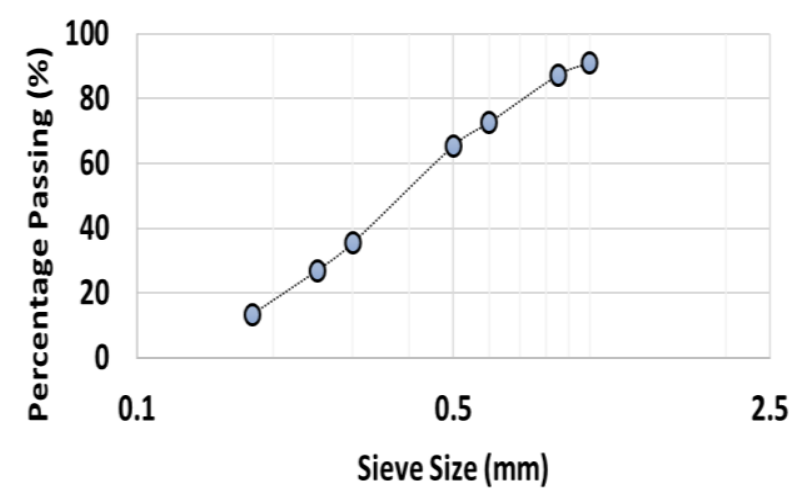

Figure 2: Particle Size Distribution Curve for Ilal Amam Block Factory

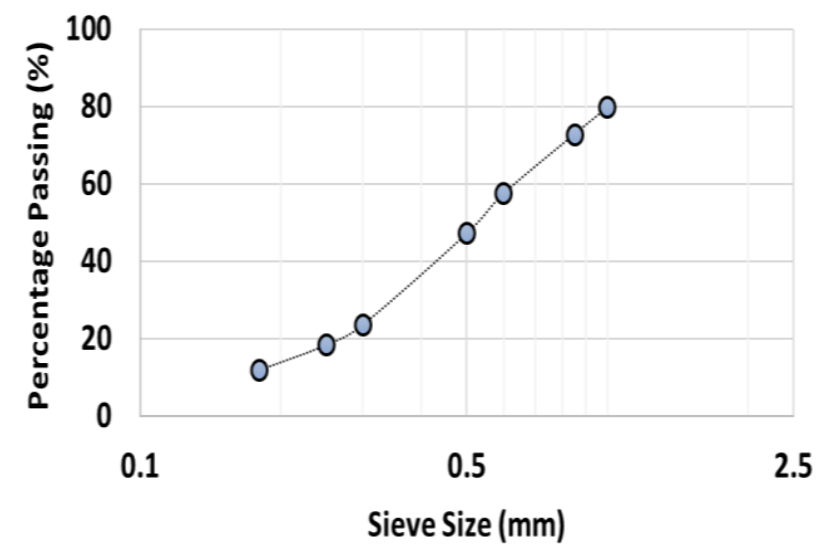

Figure 4: Particle Size Distribution Curve for M. Nuhu Block Factory

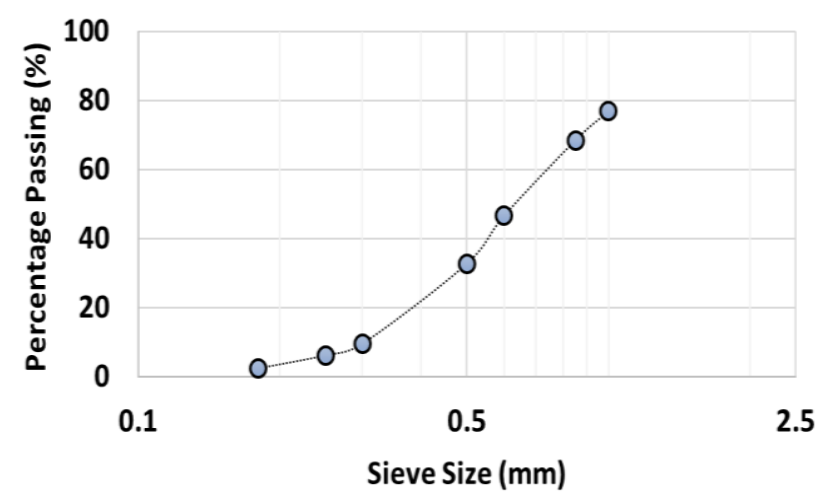

Figure 6: Particle Size Distribution Curve for Alhaji Niyi Block Factory

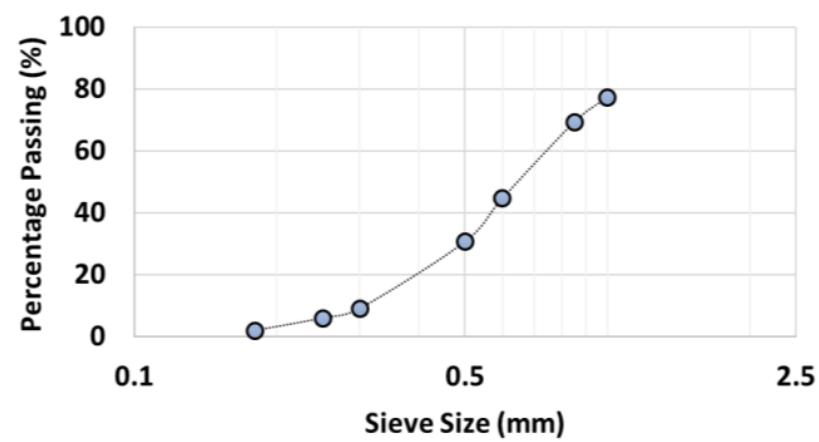

Figure 8: Particle Size Distribution Curve for Wopa Block Factory 
Table 1: Specific Gravity of Soil Samples

\begin{tabular}{lccccc}
\hline $\begin{array}{c}\text { Block } \\
\text { Industries }\end{array}$ & $\begin{array}{c}\text { Weight of } \\
\text { Empty Bottle } \\
\left(\mathrm{W}_{1}\right)\end{array}$ & $\begin{array}{c}\text { Weight of Empty } \\
\text { bottle + Dry } \\
\text { Sample }\left(\mathrm{W}_{2}\right)\end{array}$ & $\begin{array}{c}\text { Weight of Empty } \\
\text { Bottle + Soil + } \\
\text { Distilled Water }\left(\mathrm{W}_{3}\right)\end{array}$ & $\begin{array}{c}\text { Weight of Empty } \\
\text { Bottle + Distilled } \\
\text { Water }\left(\mathrm{W}_{4}\right)\end{array}$ & $\begin{array}{c}\text { Specific } \\
\text { Gravity }\end{array}$ \\
\hline Danzaria & 23.72 & 51.67 & 98.96 & 83.16 & 70.10 \\
Ilal-Amam & 21.57 & 47.19 & 84.07 & 77.78 & 2.30 \\
God is Able & 20.69 & 49.12 & 94.97 & 77.69 & 2.53 \\
M.Nuhu & 22.94 & 54.02 & 94.77 & 76.54 & 2.22 \\
Alasela & 24.18 & 47.53 & 88.09 & 82.12 & 1.97 \\
Alhaji Niyi & 24.26 & 53.64 & 99.29 & 78.52 & 2.41 \\
More & 22.04 & 52.00 & 95.92 & 81.36 & 2.39 \\
Wopa & 21.09 & 51.01 & 98.19 & & 2.29 \\
\hline
\end{tabular}

Table 2: Mix ratios adopted by block making factories

\begin{tabular}{lc}
\hline \multicolumn{1}{c}{ Block Industry } & Mix Ratio \\
\hline Danzaria & $1: 12$ \\
Ilal-Amam & $1: 12$ \\
God is Able & $1: 14$ \\
M. Nuhu & $1: 12$ \\
Alasela & $1: 13$ \\
Alhaji Niyi & $1: 10$ \\
More & $1: 12$ \\
Wopa & $1: 11$ \\
\hline
\end{tabular}

The results of the water absorption test carried out on the blocks from the eight (8) factories are shown in Figure 9. The absorption rate from the results reveals that the blocks has higher percentage of absorption rate when compared with the maximum absorption rate of $12 \%$ recommended in the NIS $87: 2000$ [7]. The result shows a considerable range of variations and values with a minimum of $13.64 \%$ and maximum of $17.39 \%$. This could be as a result of the poor mix ratios and inadequate curing of the blocks. When these blocks are exposed to persistent flooding, they become highly porous by absorbing water. Consequently, they become weakened and eventually fail.

The average of the results of the compressive strength tests of the selected sandcrete blocks from the eight (8) block making industries are shown in Figure 10. The values obtained ranges from $0.19 \mathrm{~N} / \mathrm{mm}^{2}$ to $0.40 \mathrm{~N} / \mathrm{mm}^{2}$. From the results, none of the blocks measured up to the required minimum compressive strength specified by NIS $87: 2000$ [7] of $2.5 \mathrm{~N} / \mathrm{mm}^{2}$ for non-load bearing and $3.45 \mathrm{~N} / \mathrm{mm}^{2}$ for load bearing walls. The standard deviations of the compressive results from the standard specified in [7], T-Statistic value, Degree of freedom and P-Value of the samples are shown in Table 3. The P-values for the 8 industries are less than the significance value. It can be concluded that the average compressive strengths for all the block Industries are significantly different from $2.5 \mathrm{~N} / \mathrm{mm}^{2}$.

[3] reported the compressive strengths of manual and machine compacted sandcrete blocks whose mix ratio conforms to [7]. The result revealed the $28^{\text {th }}$ day strength of manually compacted Sandcrete blocks made from Dangote cement and Elephant cement as $2.83 \mathrm{~N} / \mathrm{mm}^{2}$ and $2.89 \mathrm{~N} / \mathrm{mm}^{2}$ respectively and the $28^{\text {th }}$ day strength of machine compacted Sandcrete blocks made from Dangote cement and Elephant cement as $2.96 \mathrm{~N} / \mathrm{mm}^{2}$ and $3.03 \mathrm{~N} / \mathrm{mm}^{2}$ respectively. It can be concluded that the poor quality of the blocks from the eight (8) block industries can be attributed to the poor mix ratios adopted by the factories.

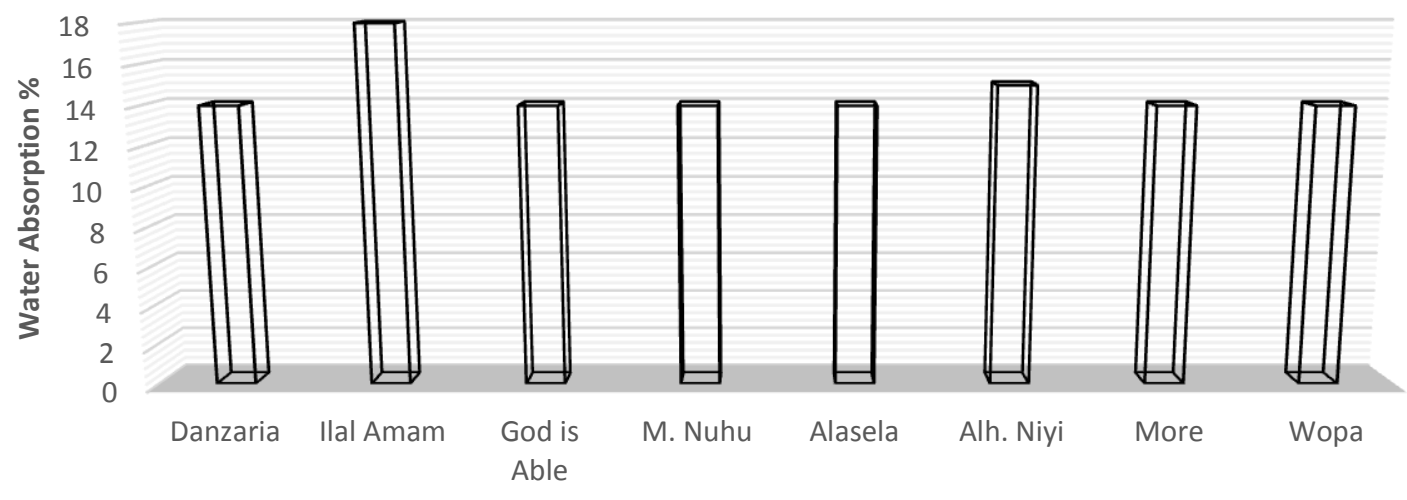

Block Factories

Figure 9: Water Absorption rate for blocks from the eight (8) block making Industries 


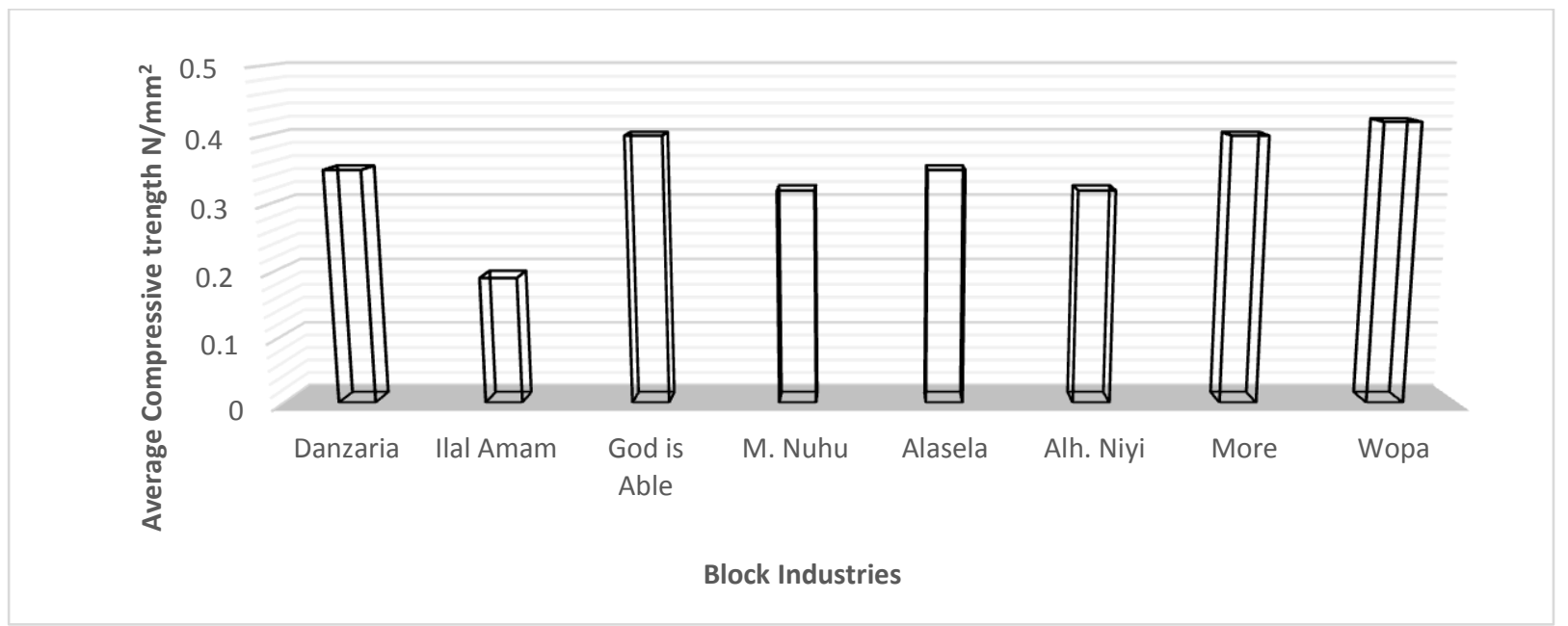

Figure 10: Average Compressive strengths of blocks from the eight (8) Block making factories

Table 3: Means and Standard deviation of the samples from the block factories

\begin{tabular}{lcccc}
\hline Block Industries & Standard Deviation & T-Statistic value & Degree of freedom & P-Value \\
\hline Danzaria & .10323 & -51.055 & 5 & .000 \\
Ilal-Amam & .11639 & -48.545 & 5 & .000 \\
God is Able & .18052 & -28.586 & 5 & .000 \\
M. Nuhu & .10926 & -48.913 & 5 & .000 \\
Alasela & .06189 & -85.295 & 5 & .000 \\
Alhaji Niyi & .06940 & -77.000 & 5 & .000 \\
More & .01633 & -314.500 & 5 & .000 \\
Wopa & .07679 & -66.402 & 5 & .000 \\
\hline
\end{tabular}

\section{CONCLUSION}

This research work assessed the rate of water absorption and the compressive strengths of sandcrete blocks produced in Adeta, Ilorin West Local Government Area, Kwara state, Nigeria. From the results obtained it was revealed that the blocks produced in Adeta did not comply with the [7] minimum standard requirement compressive strength value of $2.5 \mathrm{~N} / \mathrm{mm}^{2}$ for non-load bearing or $3.45 \mathrm{~N} / \mathrm{mm}^{2}$ for load bearing walls as well as maximum specified $12 \%$ water absorption. It is recommended that workshops and seminars should be organized periodically to enlighten producers of sandcrete blocks on the importance of adhering to Standard. Engineers should always test for compressive strength of sandcrete blocks and their rate of water absorption before recommending or allowing it for usage. Finally, government should enforce strict compliance with NIS guidelines by all block manufacturing factories in the city.

\section{REFERENCES}

[1] S. O. Odeyemi, M. A. Anifowose, M. O. Oyeleke, A. O. Adeyemi, and S. B. Bakare, "Effect of Calcium Chloride on the Compressive Strength of Concrete Produced from Three Brands of Nigerian Cement,"
American Journal of Civil Engineering. Special Issue: Predictive Estimation by ANSYS for Laminated Wood Deep Beam, vol. 3, pp. 1-5, 2015.

[2] W. O. Ajagbe, A. A. Ganiyu, and A. A. Adeniji, "Quality assessment of Sandcrete blocks in Ibadan; A review," Epistemics in Science Engineering and Technology, vol. 3 pp. 272 - 277, 2013.

[3] S. O. Odeyemi, O. O. Otunola, A. O. Adeyemi, W. O. Oyeniyan, and M. Y. Olawuyi, "Compressive strength of manual and machine compacted sandcrete hollow blocks produced from brands of Nigerian cement," American Journal of Civil Engineering. Special Issue: Predictive Estimation by ANSYS for Laminated Wood Deep Beam, vol. 3, pp. 6-9, 2015.

[4] R. Abdulwahab and M. A. Tunde, "The effects of production methods on the compressive strength of hollow sandcrete blocks," Journal of Materials and Engineering Structures, vol. 3, pp. 197-204, 2016.

[5] M. N. Anosike and A. A. Oyebade, "Sandcrete Blocks and Quality Management in Nigeria Building Industry," Journal of Engineering, Project, and Production Management, vol. 2, pp. 37-46, 2012.

[6] S. O. Odeyemi, "Effect of Types of Sandcrete Blocks on the Internal Microclimate of a Building," 
Journal of Research Information in Civil Engineering (RICE), Department of Civil Engineering, University of Ilorin, Ilorin, Nigeria, vol. 9, pp. 96-107, 2012.

[7] NIS 87:2000, "Nigerian Industrial Standard: Standard for Sandcrete blocks," ed: Standard Organisation of Nigeria, Lagos, Nigeria.

[8] D. L. N. B. Jayawardane, U. P. A. S. Ukwatta, W. M. N. R. Weerakoon, and C. K. Pathirana, "Physical and Chemical Properties of Fly Ash based Portland Pozzolana Cement," presented at the Civil Engineering Research Exchange Symposium, Faculty of Engineering, University of Ruhuna 2012.

[9] British Standard (BS-12), "Specification for Portland cement,"ed. BSI: London.

[10] NIS 444-1:2003, "Cement Pt. 1: Composition, specifications and conformity criteria for common cements," ed.

[11] British Standard (BS-882), "Specification for aggregates from natural sources for concrete," ed. London: BSI, pp. 1-9.
[12] G. D. Taylor, Materials in Construction - Principles, Practice and Performance: Pearson Publishers, 2002.

[13] British Standard (BS-3148), "Methods of test for Water for making concrete (including notes on the suitability of the water)," ed. London: BSI, pp. 1-9.

[14] NIS 554:2007, "Nigerian Standard for Drinking Water Quality," ed.

[15] A. M. Neville, Properties of Concrete, 5 ed.: Pearson Education Limited, England, 2011.

[16] J. C. Agunwamba, J. C. Ezeokonkwo, M. E. Onyia, E. Ojiogu, and A. Amadou, "Theoretical investigation of stresses distributions in hollow sandcrete blocks due to variation of cavity sizes and number web thickness," Nigerian Journal of Technology, vol. 35, pp. 254-259, 2016.

[17] A. W. Otunyo and B. N. Okechukwu, "Performance of concrete with partial replacement of fine aggregates with crushed waste glass," Nigerian Journal of Technology, vol. 36, pp. 403-410, 2017. 